\title{
PEMBEBANAN JAMINAN FIDUSIA DI INDONESIA DALAM PANDANGAN HUKUM PERLINDUNGAN KONSUMEN
}

\author{
RAHMAWATI BOTY \\ Sekolah Tinggi Ilmu Hukum Putri Maharaja Payakumbuh \\ rahmawati.boty67@gmail.com
}

\begin{abstract}
The term Standard Clause itself is not actually contained in the Civil Code or the Fiduciary Guarantee Law, therefore it needs to be linked to the Consumer Protection Law to formulate and regulate the Standard Clause. For this reason, in this study formulated problems regarding how to implement the imposition of fiduciary security and registration. This research approach method is juridical empirical. Based on the results of the research, it can be concluded that the implementation of charging and registration of fiduciary guarantees electronically is basically the same as a manual system, namely preceded by a consumer financing agreement, binding of fiduciary guarantees by notaries followed by registration which can be carried out directly by a Notary with an online system so as to give birth to a Guarantee Certificate. Fiduciary. The connection between the implementation of fiduciary agreements with consumer protection law lies in the use of standard clauses which in fact deviate from the provisions of Article 18 paragraph 1 of the Consumer Protection Law as well as legal protection for consumers and business actors who are biased and tend to pay attention to the interests of consumers only.
\end{abstract}

Keywords: Imposition, Fiduciary Guarantee, Consumer Protection.

\begin{abstract}
Abstrak: Istilah Klausula Baku sendiri sesungguhnya tidak terdapat didalam KUHPerdata maupun Undang-Undang Jaminan Fidusia, karenanya hal tersebut perlu dikaitkan dengan Undang-Undang Perlindungan Konsumen merumuskan dan mengatur mengenai Klausula Baku. Untuk itu, dalam penelitian ini dirumuskan permasalahan mengenai bagaimana pelaksanaan pembebanan serta pendaftaran Jaminan Fidusia. Metode pendekatan penelitian ini adalah yuridis empiris. Berdasarkan hasil penelitian dapat disimpulkan bahwa pelaksanaan pembebanan dan pendaftara jaminan fidusia secara elektronik pada dasarnya sama saja dengan system manual yakni didahului dengan perjanjian pembiayaan konsumen, pengikatan jaminan fidusia oleh notaries yang dilanjutkan dengan pendaftaran yang dapat dilakukan langsung oleh Notaris dengan system online sehingga melahirkan Sertipikat Jaminan Fidusia. Keterkaitan pelaksanaan perjanjian fidusia dengan Hukum perlindungan konsumen terletak pada penggunaan klausula baku yang ternyata menyimpang dari ketentuan Pasal 18 ayat 1 Undang-Undang Perlindungan Konsumen serta perlindungan hukum terhadap konsumen dan pelaku Usaha yang berat sebelah dan cenderung memperhatikan kepentingan konsumen semata.

Kata Kunci: Pembebanan, Jaminan Fiducia, Perlindungan Konsumen.
\end{abstract}

\section{A. Pendahuluan}

Dalam hal suatu benda dijaminkan dengan jaminan fidusia maka harus didaftarkan pada Kantor Pendaftaran Fidusia. Perbuatan hukum yang melahirkan jaminan fidusia adalah pendaftarannya dalam Buku Daftar Fidusia. Permohonan pendaftaran fidusia ini dilakukan oleh penerima fidusia, kuasa/wakilnya dengan 
melampirkan pernyataan pendaftaran jaminan fidusia kepada Kantor Wilayah Kementrian Hukum dan Hak Azasi Manusia pada wilayah kerja masing-masing daerah provinsi sebagai Kantor Pendaftaran Fidusia ditunjuk.

Namun dalam aplikasinya dalam praktek pada perusahaan pembiayaan selaku pelaku usaha tidak semua jaminan fidusia tersebut didaftarkan pada kantor pendaftaran fidusia. Padahal, pendaftaran jaminan fidusia yang melahirkan Sertipikat Fidusia merupakan alas hak yang kuat bagi pelaku usaha untuk "menguasai" objek jaminan dalam hal terjadinya wanprestasi. Dengan alas hak yang kuat tentu saja juga bisa melindungi perusahaan pembiayaan sebagai pelaku usaha dari akal muslihat konsumen-konsumen nakal yang beritikad tidak baik dalam melangsungkan perjanjian pembiayaan.

Dalam prakteknya, biasanya perusahaan pembiayaan telah mempersiapkan dokumen-dokumen pendukung untuk pengikatan pembiayaan dengan pembebanan jaminan secara fidusia yang merupakan accesoir (perjanjian tambahan ataupun ikutan) dari perjanjian pembiayan kendaraan bermotor sebagai perjanjian pokok konsumen dengan perusahaan pembiayaan. Dokumen-dokumen tersebut baik berupa perjanjian pembiayaan konsumen sebagai perjanjian pokok maupun perjanjian pembebanan jaminan secara fidusia sebagai perjanjian ikutan telah dibuat dan disediakan oleh perusahaan pembiayaan dalam bentuk perjanjian dengan klausula baku.

Dikatakan bersifat baku karena baik perjanjian maupun klausula tersebut, tidak dapat dan tidak mungkin dinegosiasikan atau ditawar-tawar oleh pihak lainnya. Take it or Leave it. Tidak adanya pilihan bagi salah satu pihak dalam perjanjian ini, cenderung merugikan pihak yang kurang dominan tersebut. Terlebih lagi dengan sistem pembuktian yang berlaku di negara Indonesia saat ini jelas tidaklah mudah bagi pihak yang cenderung dirugikan tersebut untuk membuktikan tidak adanya kesepakatan pada saat dibuatnya perjanjian baku tersebut, atau atas klausula baku yang termuat dalam perjanjian yang ada (Gunawan Widjaja dan Ahmad Yani, 2001).

Menurut Undang-Undang tentang Perlindungan Konsumen, Klausula Baku merupakan setiap aturan atau ketentuan dan syarat-syarat yang telah dipersiapkan dan ditetapkan terlebih dahulu secara sepihak oleh pelaku usaha yang dituangkan dalam suatu dokumen dan/atau perjanjian yang mengikat dan wajib dipenuhi oleh konsumen. Ketentuan-ketentuan didalam suatu klausula baku telah ada dan dipersiapkan terlebih dahulu oleh pelaku usaha tanpa campur tangan konsumen sehingga tidak jarang ketentuan didalamnya tidak mengakomodir kepentingan konsumen dengan seksama dan cenderung berat sebelah.

Kita tidak menampik bahwa tidak jarang Pelaku Usaha, termasuk juga Perusahaan Pembiayaan Konsumen juga kerap dirugikan oleh ulah-ulah konsumen. Berbagai modus dan tipu muslihat para konsumen nakal mulai identitas ataupun datadata palsu hingga penjualan atas bagian-bagian atau spare part kendaraan yang masih menjadi objek jaminan secara terpisah demi keuntungan pribadi dan sebagainya. Namun di sisi lain kita juga mengakui bahwa bargaining position konsumen pada prakteknya berada dibawah pelaku usaha.

Dalam rangka melindungi kedudukan konsumen yang cenderung lemah sebagai salah satu hal mendasar dalam rangka mewujudkan perlindungan terhadap konsumen, maka Undang-Undang Perlindungan Konsumen merasakan perlunya pengaturan mengenai ketentuan perjanjian baku dan/atau pencantuman klausula baku dalam setiap dokumen atau perjanjian yang dibuat oleh pelaku usaha (Gunawan Widjaja dan Ahmad Yani, 2001). Tentu dalam hal kesepakatan yang dibuat para pihak telah dituangkan dalam suatu klausula baku atau dikenal juga dengan nama Perjanjian E-ISSN: 2657-0300 Lembaga Penelitian dan Penerbitan Hasil Penelitian Ensiklopedia $\quad 341$ 
Standar, maka harus memperhatikan ketentuan dalam Pasal 18 Undang-Undang Perlindungan Konsumen mengenai larangan pencantuman Klausula Eksonerasi.

\section{B. Metodologi Penelitian}

Metode pendekatan yang digunakan dalam penelitian ini adalah penelitian yuridis empiris, yaitu penelitian yang disusun berdasarkan fakta-fakta yang ditemukan di lapangan dikaitkan dengan kaidah hukum positif yang berlaku. Dengan pendekatan tersebut dilakukan jenis penelitian deskriptif analitis yang bertujuan untuk menggambarkan peraturan perundang-undangan yang berlaku dikaitkan dengan teoriteori hukum dan praktek pelaksanaan hukum positif yang berhubungan dengan permasalahan dalam penelitian ini.

\section{Hasil dan Pembahasan}

\section{Pencantuman Klausula Baku dalam Perjanjian Fidusia}

Secara Konseptual berdasarkan Pasal 1 angka 10 Undang-Undang Perlindungan Konsumen, Klausula baku adalah setiap aturan atau ketentuan dan syarat-syarat yang telah dipersiapkan dan ditetapkan terlebih dahulu secara sepihak oleh Pelaku Usaha yang dituangkan dalam suatu dokumen dan/atau perjanjian yang mengikat dan wajib dipenuhi oleh konsumen. Dari konsep tersebut perjanjian baku dapat dikategorikan sebagai perjanjian sepihak dimana satu pihak hanya menuntut haknya saja dan membebaskan diri dari tanggung jawabnya dan pihak lain harus melaksanakan kewajibannya saja sementara hak-haknya dihilangkan. Ciri-ciri perjanjian baku sebagai berikut :

1. Bukan Perjanjian Murni;

2. Memuat syarat-syarat Eksonerasi (pengalihan tanggung jawab pembuat perjanjian baku);

3. Isi perjanjian sudah dibuat dan ditetapkan terlebih dahulu oleh satu pihak;

4. Tidak dapat dilakukan perubahan kecuali oleh pihak yang membuat perjanjian;

5. Umumnya tidak diperlukan tanda tangan pihak lainnya karena hanya berupa ketentuan umum dalam satu produk (contoh: karcis parkir)

Bila dicermati, klausula baku merupakan perjanjian sepihak yang seringkali merugikan konsumen dan menempatkan konsumen pada posisi tawar (bargaining position) yang lemah (Wahyu Fajar Waspodo \& D. Agustina, 2019). Hal ini dikarenakan setiap aturan atau ketentuan dan syarat-syarat di dalam perjanjian standar, istilah lain untuk klausula baku, telah dipersiapkan dan diterapkan terlebih dahulu secara sepihak oleh pelaku usaha sehingga konsumen tidak lagi memiliki kesempatan melakukan negoisasi terhadap syarat-syarat dan ketentuan dalam perjanjian tersebut. Sehubungan dengan sifat massal dan kolektifnya yang berlaku sama dan seragam bagi para pihak yang hendak melangsungkan perjanjian tersebut, perjanjian ini lazim juga dikenal sebagai take it or leave it contract, maksudnya adalah jika debitur menyetujui salah satu syarat-syarat, maka debitur hanya bersikap menerima atau tidak menerimanya sama sekali, kemungkinan untuk mengadakan perubahan itu sama sekali tidak ada.

Pada prinsipnya Undang-Undang tentang Perlindungan Konsumen tidak melarang pelaku usaha untuk membuat perjanjian baku yang memuat klausula baku atas setiap dokumen dan/atau perjanjian transaksi usaha perdagangan barang dan/atau jasa, selama dan sepanjang perjanjian dan/atau klausula baku tersebut tidak 
mencantumkan ketentuan sebagaimana dilarang dalam Pasal 18 ayat (1), serta tidak berbentuk sebagaimana dilarang dalam Pasal 18 ayat (2) Undang-Undang tentang Perlindungan Konsumen tersebut. Larangan pencantuman klausula baku menurut kedua pasal tersebut adalah dalam hal pencantuman klausula eksonerasi (exoneratie clausule/exemption clausule) yaitu klausula yang berisi pembebanan atau pembatasan pertanggung jawaban dari pelaku usaha kepada konsumen, serta dalam hal letak atau bentuknya sulit terlihat atau tidak dapat dibaca secara jelas, atau yang pengungkapannya sulit dimengerti. Klausula yang dilarang dicantumkan tersebut adalah:

a) menyatakan pengalihan tanggung jawab pelaku usaha;

b) menyatakan bahwa pelaku usaha berhak menolak penyerahan kembali barang yang dibeli konsumen;

c) menyatakan bahwa pelaku usaha berhak menolak penyerahan kembali uang yang dibayarkan atas barang dan/atau jasa yang dibeli oleh konsumen;

d) menyatakan pemberian kuasa dari konsumen kepada pelaku usaha baik secara langsung maupun tidak langsung untuk melakukan segala tindakan sepihak yang berkaitan dengan barang yang dibeli oleh konsumen secara angsuran;

e) mengatur perihal pembuktian atas hilangnya kegunaan barang atau pemanfaatan jasa yang dibeli oleh konsumen;

f) memberi hak kepada pelaku usaha untuk mengurangi manfaat jasa atau mengurangi harta kekayaan konsumen yang menjadi obyek jual beli jasa;

g) menyatakan tunduknya konsumen kepada peraturan yang berupa aturan baru, tambahan, lanjutan dan/atau pengubahan lanjutan yang dibuat sepihak oleh pelaku usaha dalam masa konsumen memanfaatkan jasa yang dibelinya;

h) menyatakan bahwa konsumen memberi kuasa kepada pelaku usaha untuk pembebanan hak tanggungan, hak gadai, atau hak jaminan terhadap barang yang dibeli oleh konsumen secara angsuran.

Merujuk pada konsep perjanjian standar berdasarkan Undang-Undang serta ketentuan pemberian kuasa dalam KUHPerdata, pada prinsipnya Surat Kuasa Membebankan Jaminan Fidusia termasuk kepada perjanjian dengan klausula baku. Sama halnya dengan perjanjian pembiayaan konsumen, surat kuasa membebankan jaminan fidusia ini pun dibuat dalam bentuk perjanjian standar yang memuat identitas para pihak dan segala informasi mengenai data kendaraan yang akan menjadi objek jaminan fidusia dikemudian hari. Surat Kuasa Membebankan Jaminan Fidusia, didalamnya memuat pemberian kuasa dari konsumen kepada pelaku usaha, dalam kasus ini dari konsumen debitur pembiayaan kepada Perusahaan, untuk melakukan tindakan-tindakan tertentu yang telah dituangkan dalam Surat Kuasa Membebankan Jaminan Fidusia tersebut. Kuasa ini meliputi kuasa untuk menghadap dimana perlu, memberikan keterangan-keterangan, serta memperlihatkan dan menyerahkan suratsurat yang diminta, membuat/minta dibuatkan serta menandatangani Akta Jaminan Fidusia serta surat-surat lain yang diperlukan, mendaftarkan Jaminana Fidusia tersebut, sesuai dengan syarat-syarat dan ketentuan-ketentuan yang tercantum dalam Undang-Undang No.42 Tahun 1999 tentang Jaminan Fidusia. Hal ini tentu bertentangan dengan rumusan pasal 18 ayat 1 huruf $\mathrm{h}$ Undang-Undang perlindungan Konsumen yang menyebabkan klausula tersebut batal demi hukum.

Namun dalam prakteknya, keberadaan Surat Kuasa Membebankan Jaminan Fidusia tidak dapat dilihat hanya dalam satu sisi sebagai perjanjian yang memuat klausula eksonerasi yang menyatakan bahwa konsumen memberi kuasa kepada pelaku usaha untuk pembebanan hak tanggungan, hak gadai, atau hak jaminan terhadap E-ISSN: 2657-0300 Lembaga Penelitian dan Penerbitan Hasil Penelitian Ensiklopedia $\quad 343$ P-ISSN: 2657-0319 
barang yang dibeli oleh konsumen secara angsuran. Hal ini merupakan pengalihan kewenangan dari konsumen kepada pelaku usaha melalui mekanisme pemberian kuasa untuk bertindak mewakili konsumen selaku pemilik jaminan untuk melaksanakan pembebanan jaminan fidusia. Hal tersebut dilakukan sebagai upaya pencegahan dan perlindungan bagi Pelaku Usaha dalam hal terjadinya wanprestasi yang dilakukan oleh Konsumen. Disamping itu pada dasarnya konsumen sudah mengetahui dan berarti juga telah menyetujui bahwa objek pembiayaan sekaligus dijadikan objek jaminan fidusia untuk menjamin pemngembalian piutangnya.

Penggunaan Surat Kuasa Membebankan Jaminan Fidusia pada perjanjian pembiayaan konsumen oleh Perusahaan dengan konsumen merupakan wujud dari azas kebebasan berkontrak yang memberikan pilihan bebas bagi para pihak untuk mengadakan perjanjian. Didalam asas ini terkandung suatu pandangan bahwa para pihak bebas untuk melakukan atau tidak melakukan perjanjian, bebas dengan siapa Ia mengadakan perjanjian, bebas tentang apa yang diperjanjikan dan bebas menetapkan syarat-syarat perjanjian. Menurut Sutan Remi Sjahdeni asas kebebasan berkontrak menurut hukum perjanjian Indonesia meliputi ruang lingkup sebagai berikut (Agus Yudha Hernoko, 2010):

a. kebebasan untuk membuat atau tidak membuat perjanjian

b. kebebasan untuk memilih pihak dengan siapa ia ingin membuat perjanjian

c. kebebasan untuk menentukan atau memilih kausa dari perjanjian yang akan dibuatnya

d. kebebasan untuk menentukan objek perjanjian

e. kebebasan untuk menentukan bentuk suatu perjanjian

f. kebebasan untuk menerima atau menyimpangi ketentuan undang-undang yang bersifat opsional (aanvulend, optional).

Dikaitkan dengan sebab lahirnya, suatu pemberian kuasa merupakan suatu persetujuan atau perjanjian, oleh karenanya Surat Kuasa Memberikan Jaminan Fidusia ruang lingkupnya tidak terlepas dari azas-azas di dalam perjanjian pada umumnya terutama erat kaitannya dengan Pasal 1338 KUHPerdata mengenai Asas Kebebasan Berkontrak bahwasanya semua perjanjian yang dibuat secara sah berlaku sebagai undang-undang bagi mereka yang membuatnya. Penjabaran dari ketentuan pasal ini memberikan kebebasan seluas-luasnya kepada para pihak untuk menentukan jenis perjanjian, isi serta bentuk perjanjian. Kesemuanya dengan persyaratan tidak boleh bertentangan dengan Undang-Undang, kesusilaan dan ketertiban umum (M.Sadar, Moh. Taufik Makarao, Habloel Mawardi, 2012).

Ketentuan umum dalam pemberian kuasa dapat dirujuk dalam KUHPerdata yang mengatur ketentuan-ketentuan dasar mengenai pemberian kuasa. Dalam rumusan Pasal 1792 KUHPerdata memberikan batasan mengenai pemberian kuasa bahwasanya pemberian kuasa adalah suatu perjanjian dengan mana seseorang memberikan kekuasaaan atau wewenang kepada orang lain yang menerimanya untuk atas namanya menyelenggarn suatu urusan. Sementara mengenai cara dan bentuk pemberian kuasa itu sendiri berdasarkan Pasal 1793 KUHPerdata dapat diberikan dan diterima dalam bentuk akta resmi, akta notaris, akta yang dilegalisasi di Kepaniteraan Pengadilan, akta yang dibuat oleh pejabat dan sebagainya, juga dapat diberikan dengan surat dibawah tangan, surat biasa dan dapat juga diberikan secara lisan.

Lebih lanjut dari bunyi pasal 1792 tersebut dapat diuraikan secara rinci bahwa pemberian kuasa tidak lain adalah suatu persetujuan atau perjanjian. Apabila melihat 
dari sifat perjanjian,maka pemberian kuasa ini adalah merupakan perjanjian khusus. Oleh karena pemberian kuasa merupakan suatu perjanjian, maka di dalamnya menimbulkan hak dan kewajiban di antara para pihak. Namun penerima kuasa berhak untuk menolak atau melepaskan kuasa itu, begitu pun sebaliknya pemberi kuasa berhak untuk mencabut kuasa tersebut. Penerima kuasa dalam hal ini bertindak untuk dan atas nama pemberi kuasa untuk menyelenggarakan suatu urusan. Tidak semua tindakan atau perbuatan dapat dikuasakan kepada orang/pihak lain, apabila orang/pihak yang berkepentingan tersebut berhalangan (Hasanuddin Rahman, 1995).

Sebagai bagian yang tidak terpisahkan dengan Perjanjian Pembiayaan Konsumen sebagai Perjanjian Pokoknya, Surat Kuasa Membebankan Jaminan Fidusia oleh Perusahaan pada dasarnya merupakan dokumen pemberian kuasa yang dibuat dibawah tangan yang nantinya dapat digunakan oleh Perseroan untuk pengikatan Jaminan Fidusia dengan Akta Notaris. Disamping itu Surat Kuasa ini juga sekaligus menjadi perjanjian fidusia antara konsumen dengan perseroan yang substansi dari Surat Kuasa Membebankan Jaminan Fidusia ini telah sekaligus mencantumkan hak Perseroan selaku penerima Fidusia dalam hal terjadinya wanprestasi oleh konsumen selaku Pemberi Fidusia.

Disamping itu, merujuk pada teori mengenai jaminan fidusia yang berasal dari kata fides atau fiduciair yang diartikan kepercayaan dimana hubungan hukum yang terjadi antara para pihak didasarkan kepada kepercayaan. Pemberi fidusia percaya bahwa penerima fidusia mau mengembalikan bukti hak kepemilikan barang jaminan setelah pelunasan piutangnya. Demikian pula kreditur percaya bahwa Pemberi Fidusia tidak akan menyalahgunakan benda jaminan yang berada dalam kekuasaannya. Prinsip fiduciair ditujukan kepada kepercayaan yang diberikan secara bertimbal balik oleh satu pihak kepada pihak lain, bahwa apa yang keluar ditampakkan sebagai pemindahan milik, sebenarnya kedalam internal bahwa haknya suatu jaminan saja untuk menjamin suatu utang (Subekti, 2001).

Fidusia merupakan salah satu cara pengoperan hak milik dari pemiliknya (debitur), berdasarkan adanya perjanjian pokok (perjanjian utang piutang) kepada kreditur, akan tetapi yang diserahkan hanya haknya saja secara yuridis levering dan hanya dimiliki oleh kreditur secara kepercayaan saja sebagai jaminan utang debitur, sedangkan objeknya tetap dikuasai oleh debitur tetapi bukan lagi sebagai eegenar atau beziteer melainkan hanya sebagai detentor atau houder dan atas nama kreditur eigenaar (H.S Salim, 2004). Dengan batasan dan pengertian tersebut menunjukkan bahwa fidusia pada prinsipnya merupakan perjanjian jaminan yang didasarkan kepada kepercayaan antara kedua belah pihak yaitu Debitur sebagai Pemberi Fidusia dengan Kreditur sebagai Penerima Fidusia. Itulah sebabnya pemberlakuan Surat Kuasa Membebankan Jaminan Fidusia dimungkinkan terutama untuk memenuhi ketentuan Undang-Undang Jaminan Fidusia yang mensyaratkan pembebanan Jaminan Fidusia dilakukan dengan akta notaris. Pada prinsipnya, Surat Kuasa Membebankan Jaminan Fidusia adalah perjanjian jaminan fidusia para pihak yang lahir berdasarkan asas kebebabasan berkontrak sehingga berlaku dan mengikat bagi para pihak. Mengingat sistem hukum perikatan yang ada dalam buku III KUHPerdata adalah open system maka semua perjanjian yang dibuat oleh kedua belah pihak dianggap sebagai suatu Undang-Undang, hal itu juga berlaku untuk perjanjian atau surat kuasa dibawah tangan dalam satu perjanjian fidusia yang berdasarkan kepercayaan. 


\section{Perlindungan Konsumen dan Pelaku Usaha dalam Jaminan Fidusia}

Sebagai suatu perjanjian yang isinya telah ditentukan sepihak oleh Pelaku Usaha, klausula baku seringkali merugikan konsumen dan menempatkan konsumen pada bargaining position (posisi tawar) yang lemah. Adanya klausula baku dalam bukti transaksi mengindikasikan bahwa Pelaku Usaha tidak beritikad baik untuk melindungi hak-hak konsumen dengan berusaha untuk melepas segala tanggungjawab setelah transaksi dan itikad baik Pelaku Usaha ukurannya bisa menjadi sangat subjektif. Karenanya diperlukan suatu instrument hukum yaitu Undang-Undang Perlindungan Konsumen yang bertujuan memberikan perlindungan terhadap konsumen. Sebagaimana asas lex specialis derogate lex generalis, Undang-Undang Perlindungan Konsumen menjadi instrumen hukum yang secara khusus dipakai jika terjadi persengkataan antara konsumen dan Pelaku Usaha. Hubungan hukum antara Konsumen dan Pelaku Usaha merupakan hubungan hukum yang timbul dari tindakan dan atau perbuatan dalam lapangan hukum perdata sehingga terhadapnya dapat dirujuk ketentuan dalam KUHPerdata. Walaupun sebenarnya bisa digunakan KUHPerdata untuk mengaturnya, namun dalam KUHPerdata tidak dikenal istilah konsumen, selain Undang-Undang Perlindungan Konsumen memang diundangkan dengan tujuan memberi perlindungan terhadap konsumen.

Dalam rangka memberikan perlindungan terhadap konsumen, Undang-Undang Perlindungan Konsumen telah merumuskan ketentuan-ketentuan yang sedemikian rupa dibentuk untuk menghindarkan konsumen dari tindakan-tindakan dan atau perbuatan pelaku usaha yang secara sepihak menguntungkan Pelaku Usaha namun menimbulkan kerugian baik secara langsung maupun tidak langsung terhadap konsumen. Upaya perlindungan tersebut dapat kita lihat pada rumusan mengenai Hak dan Kewajiban Konsumen serta Pelaku Usaha yang terdapat dalam Pasal 4 sampai dengan Pasal 7 Undang-Undang Perlindungan Konsumen sebagai berikut:

1. Hak-hak Konsumen sesuai Pasal 5 Undang-Undang Perlindungan Konsumen adalah :

a. Hak atas kenyamanan, keamanan dan keselamatan dalam mengkonsumsi barang dan/atau jasa;

b. Hak untuk memilih barang dan/atau jasa serta mendapatkan barang dan/atau jasa tersebut sesuai dengan nilai tukar dan kondisi serta jaminan yang dijanjikan;

c. Hak atas informasi yang benar, jelas dan jujur mengenai kondisi dan jaminan barang dan/atau jasa;

d. Hak untuk didengar pendapat dan keluhannya atas barang dan/atau jasa yang digunakan;

e. Hak untuk mendapatkan advokasi, perlindungan dan upaya penyelesaian sengketa perlindungan konsumen secara patut;

f. Hak untuk mendapat pembinaan dan pendidikan konsumen;

g. Hak untuk diperlakukan atau dilayani secara benar dan jujur serta tidak diskriminatif;

h. Hak untuk mendapatkan kompensasi, ganti rugi/penggantian, apabila barang dan/atau jasa yang diterima tidak sesuai dengan perjanjian atau tidak sebagaimana mestinya;

i. Hak-hak yang diatur dalam ketentuan peraturan perundang-undangan lainnya. 
2. Pasal 5 Undang-undang Perlindungan Konsumen juga memuat kewajiban konsumen sebagai berikut:

a. Membaca atau mengikuti petunjuk informasi dan prosedur pemakaian atau pemanfaatan barang dan/atau jasa, demi keamanan dan keselamatan;

b. Beritikad baik dalam melakukan transaksi pembelian barang dan/atau jasa;

c. Membayar sesuai dengan nilai tukar yang disepakati;

d. Mengikuti upaya penyelesaian hukum sengketa perlindungan konsumen secara patut.

3. Hak pelaku usaha sebagaimana diatur dalam Pasal 6 Undang-undang perlindungan konsumen adalah:

a. hak untuk menerima pembayaran yang sesuai dengan kesepakatan mengenai kondisi dan nilai tukar barang dan/atau jasa yang diperdagangkan

b. hak untuk mendapat perlindungan hukum dari tindakan konsumen yang beritikad tidak baik

c. hak untuk melakukan pembelaan diri sepatutnya di dalam penyelesaian hukum sengketa konsumen

d. hak untuk rehabilitasi nama baik apabila terbukti secara hukum bahwa kerugian konsumen tidak diakibatkan oleh barang dan/atau jasa yang diperdagangkan

e. hak-hak yang diatur dalam ketentuan peraturan perundang-undangan lainnya.

4. Kewajiban pelaku usaha menurut ketentuan Pasal 7 Undang-undang perlindungan konsumen adalah:

a. beritikad baik dalam melakukan kegiatan usahanya;

b. memberikan informasi yang benar, jelas dan jujur mengenai kondisi dan jaminan barang dan/atau jasa serta memberi penjelasan penggunaan, perbaikan dan pemeliharaan;

c. memperlakukan atau melayani konsumen secara benar dan jujur serta tidak diskriminatif;

d. menjamin mutu barang dan/atau jasa yang diproduksi dan/atau diperdagangkan berdasarkan ketentuan standar mutu barang dan/atau jasa yang berlaku;

e. memberi kesempatan kepada konsumen untuk menguji, dan/atau mencoba barang dan/atau jasa tertentu serta memberi jaminan dan/atau garansi atas barang yang dibuat dan/atau yang diperdagangkan;

f. memberi kompensasi, ganti rugi dan/atau penggantian atas kerugian akibat penggunaan, pemakaian dan pemanfaatan barang dan/atau jasa yang diperdagangkan;

g. memberi kompensasi, ganti rugi dan/atau penggantian apabila barang dan/atau jasa yang dterima atau dimanfaatkan tidak sesuai dengan perjanjian.

Disamping segala ketentuan mengenai hak dan kewajiban konsumen dan pelaku usaha dalam pasal-pasal tersebut diatas, upaya untuk memberikan perlindungan terhadap konsumen juga dituangkan dalam Pasal-Pasal mengenai Perbuatan Yang Dilarang Bagi Pelaku Usaha yang diatur dalam Pasal 8 sampai dengan Pasal 17 Undang-Undang Perlindungan Konsumen. Dengan rumusan mengenai hak dan kewajibannya masing-masing serta batasan yang diberikan terhadap perbuatan yang dilarang bagi Pelaku Usaha merupakan tindakan prefentif yang dilakukan untuk memberikan perlindungan terhadap konsumen dari jerat merugikan Pelaku Usaha. Demikian pula halnya dengan tanggungjawab Pelaku Usaha yang diatur dalam Bab VI mulai dari pasal 19 sampai dengan pasal 28 juga merupakan upaya dalam rangka memberikan perlindungan hukum bagi konsumen atas tindakan dari pelaku usaha. 
Disamping itu, dalam pasal 18 Undang-Undang Perlindungan Konsumen juga mengatur mengenai larangan pencantuman klausula baku dalam perjanjian sebagaimana telah dibahas pada sub bab sebelumnya. Ketentuan Pasal 18 ayat 3 Undang-Undang Perlindungan Konsumen menegaskan bahwa setiap klausula baku yang telah ditetapkan oleh Pelaku Usaha pada bukti transaksi yang mencantumkan ketentuan sebagaimana yang dimaksud dalam Pasal 18 ayat 1 dinyatakan batal demi hukum. Sebagai suatu azas hukum yang berlaku universal, asas keseimbangan juga erat kaitannya dengan kedudukan para pihak dalam perjanjian. Setiap perjanjian yang dibuat sejogjanya menempatkan posisi para pihak termasuk konsumen dan pelaku usaha dalam kedudukan yang seimbang. Menurut Konrad Zwieght dan Hein Kotz, kebebasan berkontrak yang sebenarnya akan eksis jika para pihak didalam kontrak memiliki keseimbangan secara ekonomi dan sosial. Namun pada kenyataannya perkembangan kebutuhan dalam masyarakat modern telah menempatkan posisi konsumen dan pelaku usaha yang tidak lagi seimbang dimana konsumen sebagai pengguna barang dan/atau jasa cenderung berada pada posisi yang lebih rendah dibanding pelaku usaha sebagai penyedia barang dan/atau jasa. Hal tersebut ditambah lagi dengan penggunaan klausula baku yang secara sepihak dibuat oleh pelaku usaha sehingga timbul kecendrungan memperhatikan kepentingan sepihak semata.

Dalam situasi inilah muncul campur tangan pemerintah dalam rangka melindungi kepentingan konsumen melalui Undang-Undang Perlindungan Konsumen. Namun demikian, hal tersebut bukanlah menjadi suatu pembenaran bahwa UndangUndang Perlindungan Konsumen lebih mementingkan perlindungan terhadap konsumen semata padahal secara tegas pada penjelasan Pasal 2 Undang-Undang Perlindungan Konsumen menyebutkan salah satu asas dalam penyelenggaraan perlindungan konsumen adalah asas keseimbangan yang dimaksudkan untuk memberikan keseimbangan antara kepentingan konsumen, pelaku usaha dan pemerintah dalam arti materiil dan spiritual. Kita semua setuju bahwa perkembangan dalam kebutuhan masyarakat modern dan penggunaan klausula baku dalam kontrak komersial telah menempatkan konsumen dalam posisi yang lemah dibandingkan dengan pelaku usaha namun kita juga tidak biasa mengabaikan bahwa tidak jarang ulah konsumen seringkali menimbulkan kerugian terhadap pelaku usaha. Karenanya Undang-Undang Perlindungan Konsumen harus benar-benar mewujudkan asas keseimbangan dalam hubungan hukum konsumen dan pelaku usaha.

\section{Penutup}

Perlindungan konsumen dan pelaku usaha dalam jaminan fidusia dilihat dari perseptif Hukum Perlindungan Konsumen tidak sesuai dengan asas keseimbangan sebagai salah satu asas penyelenggaraan perlindungan konsumen dimana dalam Undang-Undang Perlindungan Konsumen lebih menitik beratkan pada upaya perlindungan terhadap konsumen. Namun dengan pembebanan dan pendaftaran jaminan fidusia dapat lebih melindungi hak-hak dan kepentingan serta memberikan jaminan kepastian hukum bagi para pihak.

\section{Daftar Pustaka}

Abdul Halim Barkatullah, Hukum Perlindungan Konsumen, FH. Unlam Press, Banjarmasin, 2008

Abdul Kadir Muhammad, Hukum Perikatan, Citra Adytia Bhakti, Bandung, 1992 
Abdul Kadir Muhammad dan Rilda Murniati, Lembaga Keuangan dan Pembiayaan, Citra Adytia Bakti, Bandung, 2004

Ahmadi Miru dan Sakka Pati, Hukum Perikatan, Penjelasan Makna Pasal 1233 sampai 1456 BW, Raja Grafindo Persada, Jakarta, 2008

Ahmadi Miru dan Sutarman Yodo, Hukum Perlindungan Konsumen, Raja Grafindo Persada, Yogyakarta, 2004

Agus Yudha Hernoko, Asas Proporsionalitas dalam Kontrak Komersial, Prenada Media Group, Jakarta, 2010

Az. Nasution, Hukum Perlindungan Konsumen Suatu Pengantar, Diadit Media, Jakarta, 1997

Gunawan Widjaja dan Ahmad Yani, Hukum Tentang Perlindungan Konsumen, Gramedia Pustaka Utama, Jakarta, 2001

Hasanuddin Rahman, Aspek-aspek Hukum Pemberian Kredit Perbankan di Indonesia, Citra Adytia Bakti, Bandung, 1995

H.Salim HS, Perkembangan Hukum Jaminan di Indonesia, Raja Grafindo Persada, Jakarta, 2004

H. Tan Kamelo, Hukum Jaminan Fidusia, Alumni, Bandung, 2004

Johannes Ibrahim, Cross Refault \& Cross Collateral Sebagai Upaya Penyelesaian Kredit Bermasalah, Refika Aditama, Bandung, 2004

M.Hasbi, Perancangan Kontrak (Dalam Teori dan Implementasi), Fakultas Hukum Universitas Andalas, Padang, 2011

M. Yahya Harahap, Segi-Segi Hukum Perjanjian, Alumni, Bandung, 1986

Oey Hoey Tiong, Fidusia sebagai Jaminan Unsur-Unsur Perikatan, Ghalia Indonesia, Jakarta 1983

Pedoman Penulisan Usulan Penelitian dan Tesis, Program Studi Magister Hukum, Program Pasca Sarjana Universitas Andalas, Padang, 2009

Rachmadi Usman, Hukum Jaminan Keperdataan, Sinar Grafika, Jakarta, 2009

Shidarta, Hukum Perlindungan Konsumen Indonesia, Gramedia Widiasarana Indonesia, Jakarta, 2006

Subekti, Aneka Perjanjian, Alumni, Bandung, 1975. 